\title{
Agroeconomic Rationale for Applying Mineral Fertilizers to Cereal Crops in West Siberia
}

\author{
Eremina Diana \\ Department of Mathematics and Informatics \\ Federal State Budgetary Educational \\ Institution of Higher Education \\ «Northern Trans-Ural State Agricultural University» \\ Tyumen, Russia \\ soil-tyumen@yandex.ru
}

\begin{abstract}
In a market economy, agricultural enterprises have switched to a new system for planning and justifying the arable yielding capacity. Soil cover patterns in West Siberia are very diverse. From an economic point of view this raises certain difficulties relating to the formation of crop yields. The given work is based on the results of long-term studies obtained at the Department of Soil Science and Agrochemistry of the Northern Trans-Ural State Agricultural University. The author performs the calculation of the crop yield generated on the main soils of West Siberia. To obtain 3.0 tons per hectare of spring wheat on leached chernozem, it is required to apply up to $180 \mathrm{~kg}$ of ammonium nitrate. On other soil patterns, it is necessary to provide for the use of nitrogen-phosphorus fertilizers. To ensure generation of $4.0 \mathrm{t} / \mathrm{ha}$ of spring wheat on sod-podzolic and gray forest soils, $340-350 \mathrm{~kg}$ of ammonium nitrate and $340-400 \mathrm{~kg}$ of ammophos per hectare are required. The probability of obtaining $4.0 \mathrm{t} / \mathrm{ha}$ and $5.0 \mathrm{t} / \mathrm{ha}$ is 76 and $47 \%$, respectively. With the increase in the planned yield, the role of mineral fertilizers increases substantially and, at the existing prices for fertilizers and grain, makes cultivation unprofitable. The economic threshold for cereal crops grown on chernozems in West Siberia is estimated to be 4.0 t/ha while on gray forest soils it is no more than $2.5 \mathrm{t} / \mathrm{ha}$. Light gray and podzolic soils are characterized by very low nutrient potential. To obtain 2.0 and more $t /$ ha of grain it is mandatory to apply mineral fertilizers to such soils. This leads to a substantial increase in the cost of money and a decrease in the profitability of growing cereal crops at existing grain prices.
\end{abstract}

Keywords - Mineral fertilizers, soil fertility, crop yield, West Siberian soils, profit, profitability.

\section{INTRODUCTION}

The introduction of intensive technologies for the cultivation of grain crops in modern market conditions requires constant monitoring of the ratio of the cost of the product and the cost of production. The selling price for food grains in Russia varies less significantly than fuel prices and those for mineral fertilizers. Therefore, specialists involved in the agriculture industry annually have to adjust business plans based on the crop yield and the market price. Therefore, it is necessary to change the approach to justification and generation of the planned yield. One of the indicators that must be taken into account is the share of the crop that is formed due to the application of mineral fertilizers. One can justify the efficiency of fertilizers not only in rubles but in grain equivalent as well.

From agricultural perspective West Siberia is a promising territory. It is generally accepted that this area is of little use for obtaining grain, especially for food purposes. However, climate change has made it possible $[1,2]$. Thanks to scientists, new varieties of grain as well as cattle breeds able to live successfully in the conditions of Siberia have been developed [3-5]. One of the factors that significantly influence crop farming in West Siberia is the soil cover and peculiar soil formation conditions [6]. The fields are located on soils with different levels of fertility, ranging from podzolic to chernozem. For each type of soil, a different amount of fertilizer is needed to obtain the same crop of cereals. In addition, it is necessary to take into account other indicators of fertility including acid-base characteristics, moistening, temperature regime, etc. This has only recently become possible, when ITtechnologies, mathematical modeling and scientifically-based systems of agriculture were incorporated in agriculture $[7,8]$.

Agri-entrepreneurs often ask: "How much of fertilizers do you need to apply to get the maximum profit?" It's rather difficult to answer it. As shown by the studies of leading West Siberian scientists [9], the Trans-Urals forest-steppe zone can produce 5.0, and in some years, $6.0 \mathrm{t} /$ ha of cereals. However, in production yields rarely exceed $4.0 \mathrm{t} / \mathrm{h}$. The reason for this can be both the wrong justification of the system of fertilizers and soil cultivation and the lack of quality seeds [10]. It is still debatable because there should be individual approach. It is necessary to address a multitude of factors, starting with the fertility of soils and ending with the organizational and economic characteristics of agricultural enterprises [11-15]. The author will try to justify the choice of yields taking into account the prices for mineral fertilizers, as they are a powerful means of increasing yields. The fuel cost and the cost of agricultural equipment are not calculated because they will exist even in the absence of fertilizers.

The purpose of the research is the agroeconomic rationale for the application of mineral fertilizers to cereal crops in West Siberia. 


\section{SUBJECTS AND METHODS}

The economic efficiency from the application of mineral fertilizers was analyzed on the basis of the long-term studies gained at the Department of Soil Science and Agrochemistry of the State Agrarian University of the Northern Trans-Ural State Agricultural University. This department has been involved in a series of experiments with mineral fertilizers for 20 years. The scheme of experiments is presented below:

Control and formation of the grain crop of spring wheat and oats due to the natural fertility of arable chernozem. Fertilizers are not applied;

Fertilization (NPK) for the planned yield in $3.0 \mathrm{t} /$ ha of grain;

NPK for the planned yield in $4.0 \mathrm{t} / \mathrm{ha}$;

NPK for the planned yield in $5.0 \mathrm{t} / \mathrm{ha}$;

NPK for the planned yield in $6.0 \mathrm{t} / \mathrm{ha}$.

The amount of fertilizers is calculated annually taking into account nutrient potential of soils and biological characteristics of agricultural crops. The calculation method is fairly simple but at the same time very accurate. It is suitable for different soils, plants and types of fertilizers.

The study soil is leached clayey loamy chernozem with evident features and properties [16]. To calculate the economic efficiency, the sod-pozolic, gray forest areas were selected as the object of study, the fertility indicators were averaged over the agricultural zone of the Tyumen region.

The calculation of costs to obtain planned harvests of grain crops was carried out using an electronic technological map created in Microsoft Excel by the Department of Mathematics and Informatics.

\section{RESULTS}

The depth of the arable sod-podzolic and light-gray forest layer on average in the south of the Tyumen region reaches 18 $\mathrm{cm}$. The thickness of the arable dark gray forest layer and leached chernozems usually reaches $25-27 \mathrm{~cm}$, while the humus layer is $30-40 \mathrm{~cm}$. Such a strong variation in the thickness of the humus layer over arable land indicates the need for an individual approach to the choice of crop cultivation technology. An important factor to achieve the increase in the productivity of plants is mineral fertilizers. The author calculated the amount of mineral fertilizers for the planned yields for different soils in West Siberia (Fig. 1). The production of $2.0 \mathrm{t} / \mathrm{ha}$ of grain on sod-podzolic and light gray forest soils is possible with the application of $105 \mathrm{~kg}$ of ammonium nitrate and $130 \mathrm{~kg}$ of ammophos, whereas on dark gray forest and leached chernozem only $40 \mathrm{~kg}$ and $20 \mathrm{~kg}$ of ammonium nitrate are needed, respectively. The production of $3.0 \mathrm{t} / \mathrm{ha}$ is possible only with ammophos applied to sodpodzolic $-260 \mathrm{~kg} / \mathrm{ha}$; gray forest $-200 \mathrm{~kg} / \mathrm{ha}$; dark gray forest $-80 \mathrm{~kg} / \mathrm{ha}$.

The yield in 4,0 t/ha on sod-podzolic and light gray forest soils will require $220 \mathrm{~kg}$ of ammonium nitrate, which is $15 \%$ more than the amount used on leached chernozem. Ammophos is needed in the amount of $400 \mathrm{~kg} / \mathrm{ha}$, which is 3.5 times more than that required on leached chernozem. On dark gray forest soils, the amount of ammophos needed to produce $4.0 \mathrm{t} / \mathrm{ha}$ is almost 2 times higher than that used on leached chernozem. No significant differences were noted with regard to the use of ammonium nitrate.

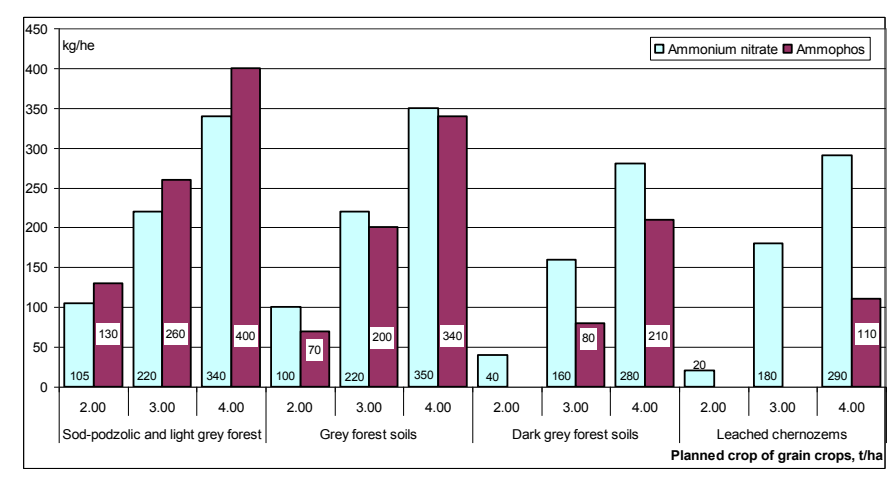

Fig.1. - Amount of estimated mineral fertilizers to produce crop yeilds on different soil patterns in West Siberia, $\mathrm{kg} / \mathrm{ha}$

Along with the natural nutrient potential in different types of soils, for agroeconomic reasons it is necessary to take into account weather conditions in West Siberia that differ from European values. As shown by the scientific research, even full provision of plants with food does not guarantee the planned harvest.

The average yield in spring wheat over the years of research was $2.01 \mathrm{t} / \mathrm{ha}$, varying in certain years from 1.42 to $3.2 \mathrm{t} / \mathrm{ha}$. Mineral fertilizers applied according to the scheme of experience made it possible to analyze the planned yield in the agricultural area of the Tyumen region. Fertilization for a yield in $3.0 \mathrm{t} /$ ha makes it possible to improve the conditions necessary for the growth of spring wheat and to a lesser extent depend on weather conditions. The probability to obtain a yield in $3.0 \mathrm{t} / \mathrm{ha}$ with the existing farming system is $100 \%$, which has been repeatedly proved in production conditions. Mineral fertilizers per planned yield in $4.0 \mathrm{t} / \mathrm{ha}$ on average over the years of research allowed to obtain the desired result, i.e. $3.68 \mathrm{t} / \mathrm{ha}$. The probability to obtain $4.0 \mathrm{t} / \mathrm{ha}$ is $76 \%$, which is reachable for the agricultural entrepreneur.

Further increase in the mineral nutrition made it possible to obtain the planned yield $(5.0 \mathrm{t} / \mathrm{ha}$ and $6.0 \mathrm{t} / \mathrm{ha})$ only in certain years, which negatively affected the average values of $4.23 \mathrm{t} / \mathrm{ha}$ and $4.45 \mathrm{t} / \mathrm{ha}$, respectively. The probability to form $5.0 \mathrm{t} / \mathrm{ha}$ of grain is only $45 \%$, which in current market conditions is unacceptable for the agri-entrepreneur. The probability to obtain $6.0 \mathrm{t} / \mathrm{ha}$ is minimal $-9 \%$. It should be noted that such high amount of fertilizers (N270P115 kilograms of rate of application per hectare) in the worst years has a negative effect on spring wheat. This leads to a decrease in yields to critical values - 1.60-1.80 t/ha. Such a low yield formed in conditions of high soil fertility causes the situation when nitrogen fertilizers are not consumed in the year they are applied. In West Siberia, they can migrate beyond the root layer and lead to nitrate contamination of groundwater.

Widespread evaluation of fertilization effectiveness from the agronomic point of view refers to the payback on a unit of fertilizer due to additional products. The effectiveness of 
mineral fertilization is determined by comparing the yields obtained with and without fertilizers (D):

$$
D=A / B * 100 \%
$$

where $D$ is the yield share obtained through the application of mineral fertilizers, $\%$

$A$ is yield increase from fertilizers, $\mathrm{t} / \mathrm{ha}$;

$B$ is average yield when applying fertilizers, $\mathrm{t} / \mathrm{ha}$.

In those years when planned yield was obtained, the increase due to different fertilization options applied to $5.0 \mathrm{t} / \mathrm{ha}$ and $6.0 \mathrm{t} / \mathrm{ha}$ of grain is $2.92 \mathrm{t} / \mathrm{ha}$ and $3.71 \mathrm{t} / \mathrm{ha}$, respectively, with a controlled yield in $2.42 \mathrm{t} / \mathrm{ha}$ (Table 1 ).

The analysis of the yield share formed due to mineral fertilizers $(A)$ showed that it increases with the yield rise. The minimum value $(29.5 \%)$ was noted on the variant with a planned yield in $3.0 \mathrm{t} / \mathrm{ha}$. This indicates that the formation of crop is mainly due to soil fertility, and mineral fertilizers only supplement the missing element, particularly nitrogen. The application of fertilizers to yields of 5.0 and $6.0 \mathrm{t} / \mathrm{ha}$ increased the share of yields up to $51.2-53.3 \%$.

TABLE I. PAYBACK ON MINERAL FERTILIZERS AND THEIR MASS (A) IN THE FORMATION OF HARVEST

\begin{tabular}{|l|l|l|l|l|}
\hline \multicolumn{1}{|c|}{ Variant } & $\begin{array}{c}\text { Harvest, } \\
\text { t/ha }\end{array}$ & $\begin{array}{c}\mathbf{A}, \\
\%\end{array}$ & $\begin{array}{c}\text { Mass of } \\
\text { fertilizers, } \\
\text { kg /ha }\end{array}$ & $\begin{array}{c}\text { Payback on } \\
\text { 1 kg of } \\
\text { fertilizers, } \\
\text { kg of grain }\end{array}$ \\
\hline \multicolumn{5}{|l|}{ At an average yield over the years of research } \\
\hline Control & 2,08 & - & - & - \\
\hline NPK for 3.0 t/ha & 2.95 & 29.5 & 108 & 27.2 \\
\hline NPK for 4.0 t/ha & 3.71 & 44.0 & 173 & 21.5 \\
\hline NPK for 5.0 t/ha & 4.26 & 51.2 & 267 & 16.0 \\
\hline NPK for 6.0 t/ha & 4.45 & 53.3 & 385 & 11.6 \\
\hline When obtaining the planned yield in the years of research \\
\hline Control & 2.42 & - & - & - \\
\hline NPK for 3.0 t/ha & 3.34 & 27.5 & 98 & 34.3 \\
\hline NPK for 4.0 t/ha & 4.30 & 43.6 & 176 & 24.4 \\
\hline NPK for 5.0 t/ha & 5.34 & 54.6 & 291 & 18.4 \\
\hline NPK for 6.0 t/ha & 6.14 & 60.5 & 421 & 14.6 \\
\hline
\end{tabular}

The payback on $1 \mathrm{~kg}$ of applied fertilizers with the planned harvest of grain amounting to $3.0 \mathrm{t} / \mathrm{ha}$ is $27.2 \mathrm{~kg}$ of grain, which is the maximum value among the studied options. The minimum value $(11.6 \mathrm{~kg})$ was noted with the NPK for $6.0 \mathrm{t} / \mathrm{ha}$ option, which is explained by the failure to achieve the planned yield on average over the years of research. To forecast and justify the level of nutrition, it is better to use the payback on fertilizers due to the crop increase. The maximum payback on fertilizers will be with the NPK of $4.0 \mathrm{t} /$ ha option with $9.5 \mathrm{~kg}$ of grain, while with the maximum fertilization it amounts to 6.2 $\mathrm{kg}$. These values can be used to calculate the risk of investing in fertilizers and obtaining the planned yield. If the cost of increased grain value exceeds the cost of $1 \mathrm{~kg}$ of active mineral fertilizers, it can be expected that the costs will be paid off even when yields are less than planned. In the years when the obtained grain makes up $5.0 \mathrm{t} / \mathrm{ha}$ and $6.0 \mathrm{t} / \mathrm{ha}$, the payback on 1 $\mathrm{kg}$ of fertilizers is 18.4 and $14.6 \mathrm{~kg}$ of grain, which is $2.0-2.4 \mathrm{~kg}$ more than the average calculated yield values. The payback on fertilizers due to the increased crop in the option with $6.0 \mathrm{t} / \mathrm{ha}$ of grain is $8.8 \mathrm{~kg}$, which is also the minimum value. This is justified by the fact that the increase is formed solely through the application of mineral fertilizers.

Economic efficiency was calculated at the following cost of fertilizers: namely, ammonium nitrate - 16,000 rubles per tonne; double superphosphate $-24,000 \mathrm{rub}$. The price of diesel fuel and gasoline is 55,714 and 52,860 rubles per tonne. The spring wheat production in the northern forest-steppe of the Tyumen region, even in the absence of mineral fertilizers, meets the requirements to food grain, so the selling price is 8,000 rubles per tonne. The calculations show that the expenses at the control rate are $16,628 \mathrm{RUB} /$ ha at the cost of 1 tonne of grain equal to 5,992 rubles. Besides, the profit is $4,174 \mathrm{RUB} / \mathrm{ha}$, which is the minimum indicator among the studied options. Profitability is also minimal $-33.5 \%$. It should be noted that gluten content during cultivation without fertilizers can be reduced to $20-22 \%$, which is unacceptable for food grains and the selling price maybe twice less (forage grain), which will make spring wheat growing unprofitable.

Fertilization increases the expenses up to $16,560-25,360$ RUB/ha but the increased yield makes it possible to increase the cost of production that varies from 23,590 to $3,558 \mathrm{RUB} / \mathrm{ha}$. The maximum profit was noted on the option with fertilization of $5.0 \mathrm{t} / \mathrm{ha}$ and amounted to13,205 rubles with the profitability of $63.3 \%$.

Further increase in the level of nutrition led to an increase in costs, but the cost of production almost remained unchanged. This was due to the fact that the yield did not reach the planned values. At the same time, profitability decreased to $40.3 \%$.

The analysis of the years where the planned yield was 6.0 $\mathrm{t} / \mathrm{ha}$ is the most interesting. Expenses for NPK for $5.0 \mathrm{t} / \mathrm{ha}$ and $6.0 \mathrm{t} /$ ha options remained practically unchanged regarding the calculations at an average yield - the excess was 7-9\%, whereas the cost of production in these options was $18-29 \%$ higher. The maximum profit was obtained with the NPK for $6.0 \mathrm{t} /$ ha option $-27,726 \mathrm{RUB} / \mathrm{ha}$, which is twice as more as the control rate. However, the profitability was $15.7 \%$ lower than the one obtained with the previous option and amounted to $77.1 \%$. This is owing to the fact that the yield increase is provided solely through the application of mineral fertilizers, rather than soil fertility.

The most economically viable option was the one with a planned yield in $4.0 \mathrm{t} / \mathrm{ha}$ at which the profit was $16,845 \mathrm{RUB} / \mathrm{ha}$ with a profitability of $96 \%$. This is confirmed by the fact that the application of fertilizers compensates the lack of nutrients and spring wheat generates harvest due to soil fertility. 
TABLE II COST EFFECTIVENESS OF SPRING WHEAT GROWING WHEN APPLYING FERTILIZERS FOR PLANNED HARVEST

\begin{tabular}{|c|c|c|c|c|c|}
\hline Variant & $\begin{array}{c}\text { Cost of } \\
\text { produc } \\
\text { tion, } \\
\text { RUB/h } \\
\text { a }\end{array}$ & $\begin{array}{c}\text { Expens } \\
\text { es, } \\
\text { RUB/h } \\
\text { a }\end{array}$ & $\begin{array}{l}\text { Prime } \\
\text { cost of } \\
\text { grain, } \\
\text { t/RUB }\end{array}$ & $\begin{array}{c}\text { Profit/ } \\
\text { loss, } \\
\text { RUB. }\end{array}$ & $\begin{array}{c}\text { Profita } \\
\text { bility, } \\
\%\end{array}$ \\
\hline \multicolumn{6}{|c|}{ At an average yield over the years of research } \\
\hline Control & 16628 & 12454 & 5992 & 4174 & 33.5 \\
\hline NPK for $3.0 \mathrm{t} / \mathrm{ha}$ & 23590 & 16560 & 5616 & 7030 & 42.5 \\
\hline NPK for $4.0 \mathrm{t} / \mathrm{ha}$ & 29699 & 17834 & 4804 & 11865 & 66.5 \\
\hline NPK for $5.0 \mathrm{t} / \mathrm{ha}$ & 34077 & 20872 & 4900 & 13205 & 63.3 \\
\hline NPK for $6.0 \mathrm{t} / \mathrm{ha}$ & 35580 & 25360 & 5702 & 10220 & 40.3 \\
\hline \multicolumn{6}{|c|}{ When obtaining the planned yield } \\
\hline Контроль & 19357 & 12548 & 5186 & 6809 & 54.3 \\
\hline NPK for $3.0 \mathrm{t} / \mathrm{ha}$ & 26724 & 15480 & 4634 & 11244 & 72.6 \\
\hline NPK for $4.0 \mathrm{t} / \mathrm{ha}$ & 34395 & 17550 & 4082 & 16845 & 96.0 \\
\hline NPK for $5.0 \mathrm{t} / \mathrm{ha}$ & 42710 & 22348 & 4186 & 20362 & 91.1 \\
\hline NPK for $6.0 \mathrm{t} / \mathrm{ha}$ & 49116 & 27726 & 4516 & 21390 & 77.1 \\
\hline
\end{tabular}

The correlation analysis showed a close positive relationship between yield and direct costs $(r=0,94)$, so the regression analysis can be performed and the regression equation (2) can be obtained:

$$
Y=1106+1964 \cdot X
$$

where $Y$ is direct costs for growing spring wheat, RUB/ha;

\section{$\mathrm{X}$ is the planned yield, $\mathrm{t} / \mathrm{ha}$.}

As proved by the calculations, spring wheat cultivation on sod-podzolic and light gray forest soils based on traditional cultivation technology at the existing prices for fuel, fertilizers and grain is unprofitable - even at a price of 10,000 RUB/tonne. The loss is 1,137-2,467 RUB/ha (Fig. 2).

The maximum selling price enables to make grain production profitable on gray forest soils when fertilizers are applied to the planned yield in 2.0 and $3.0 \mathrm{t} / \mathrm{ha}$, where the profit is 270 and $300 \mathrm{RUB} / \mathrm{ha}$, with a profitability of 2.8 and $3.0 \%$, respectively. However, for agricultural enterprises, such profitability is too low, therefore, it is necessary to take measures to improve the nutrient status (it is possible to apply break crops into crop rotation), which will reduce the amount of fertilizers necessary to obtain the planned yield. Moreover, it will be effective to apply resource-saving cultivation technology.

At a price of 7,000 rubles, spring wheat growing is profitable only on leached chernozem with fertilization of 3.0$4.0 \mathrm{t} / \mathrm{ha}$, the profit is 1,500 and $531 \mathrm{RUB} /$ ha with a profitability of 16.7 and $3.9 \%$, respectively. Without fertilizers, the cultivation of spring wheat on leached chernozem is unprofitable. The selling price of $10,000 \mathrm{RUB} /$ tonne makes it possible to obtain profitable grain with a maximum profitability of $66.7 \%$, when applying fertilizers to $3.0 \mathrm{t} / \mathrm{ha}$. Further increase in the level of mineral nutrition is also a profitable measure worth $6,531 \mathrm{RUB} /$ ha but less cost efficient - only $48.5 \%$. The application of fertilizers for the planned yield in $2.0 \mathrm{t} / \mathrm{ha}$ or their full exclusion will result in a 2 -fold decrease in profits $-2,227$ $\mathrm{RUB} /$ ha with a profitability of $41.8 \%$.
The use of mineral fertilizers on dark gray forest soils at the recommended selling price for grain makes it possible to achieve a positive economic effect. Profit with a yield in 2.0 $\mathrm{t} / \mathrm{ha}$ is $2,779 \mathrm{RUB} / \mathrm{ha}$, with a maximum profitability of $38.5 \%$. A further increase in the level of mineral nutrition contributes to an increase in profit to $4,283 \mathrm{RUB} / \mathrm{ha}$ but reduces the profitability of grain production. The calculations showed that fertilization for yields over $3.0 \mathrm{t} / \mathrm{ha}$ is not effective, although economically justified as costs rise by $44 \%$, while profit is only $1 \%$.

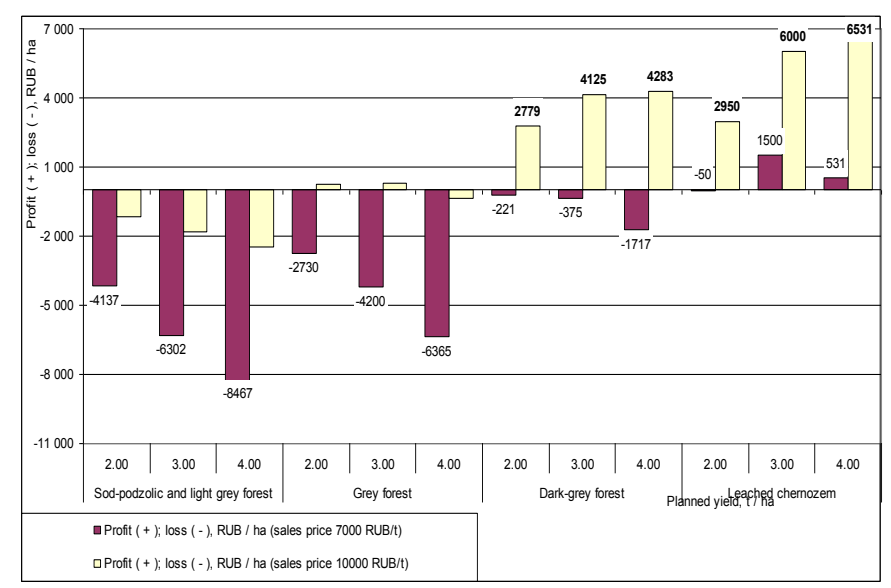

Fig. 2. Cost-effectiveness of spring wheat production at different crop selling prices, RUB/ha

The simulation of the economic situation shows that when fertilizers are applied at $3.0 \mathrm{t} / \mathrm{ha}$, where the land under cultivation is located on chernozem soils, they can sell spring wheat at 7,000 rubles per tonne, while maintaining the profitability level of 15 percent of total costs. Grain, obtained on gray forest soils, to achieve such profitability, must be sold at 11,000 rubles per tonne.

\section{CONCLUSION}

The yield in spring wheat in the northern forest-steppe on leached chernozem is $2.08 \mathrm{t} / \mathrm{ha}$ in the absence of mineral fertilizers. To obtain $3.0 \mathrm{t} / \mathrm{ha}$ of spring wheat on leached chernozem, ammonium nitrate is required in the amount of up to $180 \mathrm{~kg}$. On other soil patterns, it is necessary to provide for the use of nitrogen-phosphorus fertilizers. To form $4.0 \mathrm{t} / \mathrm{ha}$ of spring wheat grain on sod-podzolic and gray forest soils, 340$350 \mathrm{~kg}$ of ammonium nitrate and $340-400 \mathrm{~kg}$ of ammophos per hectare are required. The probability of obtaining $4.0 \mathrm{t} / \mathrm{ha}$ and $5.0 \mathrm{t} /$ ha is 76 and $47 \%$, respectively. The probability to obtain $6.0 \mathrm{t} / \mathrm{ha}$ is extremely low $-9 \%$. The application of fertilizers for the yields of $5.0 \mathrm{t} / \mathrm{ha}$ and $6.0 \mathrm{t} / \mathrm{ha}$ increases the yield share, which is formed due to TCAs to $51.2-53.3 \%$. The maximum payback on $1 \mathrm{~kg}$ of fertilizer due to obtained grain was marked when applying NPK to $3.0 \mathrm{t} / \mathrm{ha}$. With the increase in plant nutrition, the payback decreases and reaches the minimum values with the option where planned yield in $6.0 \mathrm{t} / \mathrm{ha}$ is 11.6 $\mathrm{kg}$ of grain. When obtaining the planned yield, the most economically profitable yield is $4.0 \mathrm{t} / \mathrm{ha}$, at which the maximum profitability is $120.5 \%$. The failure to receive the planned yield 
when applying fertilizers by $6.0 \mathrm{t} / \mathrm{ha}$ leads to a decrease in production cost-effectiveness up to $43.1 \%$.

\section{References}

[1] I. Kuhling, D. Redozubov, G. Broll and D. Trautz, "Impact of tillage, seeding rate and seeding depth on soil moisture and dryland spring wheat yield in Western Siberia" Soil \& Tillage Research, 2017, 170, pp. 43-52. DOI: 10.1016/j.still.2017.02.009

[2] D.T. Degefie, E. Fleischer, O. Klemm, A.V. Soromotin, O.V. Soromotina, A.V.Tolstikov and N.V. Abramov, "Climate extremes in south western Siberia: past and future" Stoch. Environ. Res. Risk Assess. 28 (2014), pp. 2161-2173. DOI: 10.1007/s00477-014-0872-9.

[3] A. Lyubimova and D. Eremin, "Laboratory varietal control as a guarantee of successful work of gribusiness in Russia," MATEC Web of Conferences, $170, \quad 2018, \quad$ pp. https://doi.org/10.1051/matecconf/201817004015

[4] Y.P. Loginov, A.A. Kazak, L.I. Yakubyshina, T.N. Falaleeva, S.N Yashchenko and E.T. Yarova, "Breeding value of collection varieties of potato in the forest-steppe zone of the Tyumen region," Journal of Pharmaceutical Sciences and Research, 1, 2018, pp. 377-380.

[5] M.A. Chasovshchikova, O.M. Sheveleva, M.A. Svjazhenina, N.I. Tatarkina, A.V. Satkeeva, A.A. Bakharev, E.A. Ponomareva and A.G. Koshchaev, "Relationship between the genetic variants of kappa-casein and prolactin and the productive-biological characteristics of cows of the black-motley breed," Journal of Pharmaceutical Sciences and Research, 9, 2017, pp. 1038-1044

[6] D.I. Eremin, "Soils swelling as a regional feature of Western Siberia," MATEC Web of Conferences, 170 pp. 02017 https://doi.org/10.1051/matecconf/201817002017

[7] D. Eremina, "IT-technologies in soil Informatics and Russian agribusiness," MATEC Web of Conferences. 170, 2018,pp. 04016. DOI: https://doi.org/10.1051/matecconf/201817004016
[8] D. Eremina, "The impact of transport infrastructure on ecological status of arable land in Western Siberia," MATEC Web of Conferences, 170, 2018, pp. 05004. DOI: https://doi.org/10.1051/matecconf/201817005004

[9] V. M. Nazaryuk, M.I. Klenova and F.R. Kalimullina, "Role of soil type and macrosymbiont genotype in aftereffect of biological nitrogen", Contemporary problems of ecology, 5, 2012, pp. 511-515. DOI: $10.1134 / \mathrm{S} 199542551205006 \mathrm{X}$

[10] F.J. Stevenson, "Cycles of soil carbon, nitrogen, phosphorus, sulfur, micronutrients", N.Y. e. a.: John Willey \& Sons, 1986, 380 c.

[11] E.V. Shein and O.A. Troshina, "Physical properties of soils and the simulation of the hydrothermal regime for the complex soil cover of the Vladimir Opol'e region," Eurasian Soil Sci. 45, 2012, pp. 968-976. DOI: $10.1134 / \mathrm{S} 1064229312100092$

[12] D.I. Eremin and N. A. Gruzdeva, “ Influence of anthropogenic factor on microaggregate composition of gray forest soils," Siberian Bulletin of agricultural science, 1, 2018, pp. 28-37. DOI: 10.26898/0370-87992018-1-4

[13] A.V. Iglovikov, "The development of artificial Phytocenosis in Environmental Construction in the far North," Procedia Engineering, 165, 2016, pp. 800-805. DOI:10.1016/j.proeng.2016.11.778

[14] D.I. Eremin, "The use of modern data about the composition and properties of soil for the development of transport infrastructure of Tyumen", [IOP Conference Series: Earth and Environmental Science, 2017, vol. 90, Conf. 1]. DOI: org/10.1088/1755-1315/90/1/012021.

[15] N. Ustinov, A. Maratkanov and A. Martynenko, "Experimental study of the parameters of the active tool of a cultivator with a frame in form a flexible tubular element," [MATEC Web of Conferences, 106, 2017, pp. 08063]. DOI: https://doi.org/10.1051/matecconf/201710608063

[16] D.I. Eremin, "Changes in the content and quality of humus in leached chernozems of the Trans-Ural forest-steppe zone under the impact of their agricultural use," Eurasian soil science, 2016, 5, pp. 538-545. DOI: $10.1134 / \mathrm{S} 1064229316050033$ 